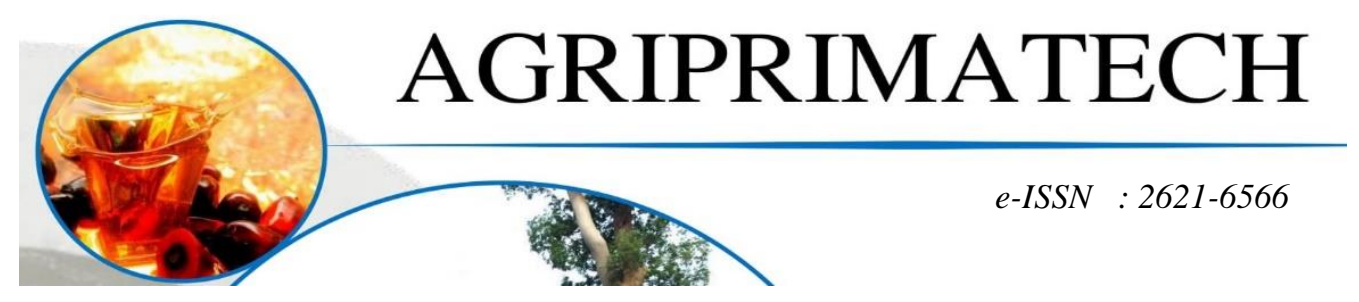

\title{
PENGARUH KOMPETENSI, PELATIHAN DAN MOTIVASI TERHADAP KINERJA DOSEN TETAP PADA UNIVERSITAS PRIMA INDONESIA
}

\author{
SALMAN FARIS ${ }^{1}$ \\ ${ }^{1}$ Fakultas Agroteknologi, Universitas Prima Indonesia, Sumatera Utara \\ E-mail: salmanfaris@gmail.com
}

\begin{abstract}
ABSTRAK
Penelitian ini bertujuan untuk mengetahui pengaruh kompetensi, pelatihan dan motivasi terhadap kinerja dosen tetap UNPRI secara parsial maupun simultan. Penelitian dilakukan terhadap dosen tetap UNPRI. Populasi dalam penelitian adalah dosen tetap UNPRI. Metode pengumpulan data dalam penelitian ini adalah kuesioner atau angket. Teknik pengambilan sampel yang digunakan adalah teknik Random Sampling. Penentuan jumlah sampel dalam penelitian ini menggunakan rumus Slovin dengan taraf kesalahan $5 \%$ sehingga diperoleh jumlah sampel sebanyak 221 dosen dari jumlah populasi sebesar 492 dosen tetap UNPRI. Uji prasyarat analisis menggunakan uji validitas, reliabilitas. Teknik analisis data menggunakan analisis deskriptif, analisis korelasi berganda, analisis regresi berganda dan koefisien determinasi dengan perhitungan menggunakan SPSS versi 20,0. Hasil penelitian yang bersumber dari pengolahan data menunjukkan hubungan yang positif antara variabel kompetensi, pelatihan dan motivasi terhadap kinerja dosen tetap UNPRI. Secara parsial pengaruh kompetensi, pelatihan dan motivasi terhadap kinerja dosen tetap UNPRI masingmasing sebesar 0,$141 ; 0,094$ dan 0,167. Secara simultan variabel kompetensi, pelatihan dan motivasi memiliki pengaruh yang signifikan terhadap kinerja dosen tetap UNPRI sebesar 0,392. Dari hasil analisis ditemukan bahwa secara parsial pengaruh kompetensi, pelatihan dan motivasi terhadap kinerja dosen tetap UNPRI masing-masing sebesar $14,1 \%$; $9,4 \%$ dan $15,7 \%$. Secara simultan pengaruh kompetensi, pelatihan dan motivasi terhadap kinerja dosen tetap UNPRI sebesar 39,20\% dan sisanya dipengaruhi oleh variabel lain yang tidak diajukan dalam penelitian ini.
\end{abstract}

Kata Kunci : Kompetensi, Pelatihan, Motivasi, Kinerja

\section{PENDAHULUAN}

Peran Perguruan Tinggi untuk menciptakan sumber daya manusia yang berdaya saing tinggi sangat besar pengaruhnya terhadap kemajuan bangsa. Untuk itu kualifikasi dosen sangat diperlukan untuk menyampaikan ilmu pengetahuan dan keterampilan agar mahasiswa memiliki kompetensi sesuai dengan tuntutan industri yang berkembang pesat. Undang-Undang Republik Indonesia Nomor 14 Tahun 2005 tentang Guru dan Dosen pasal 1 ayat (2) mendefinisikan bahw: Dosen adalah pendidik profesional dan ilmuwan dengan tugas utama mentransformasikan, mengembangkan, dan menyebarluaskan ilmu pengetahuan, teknologi, dan seni melalui pendidikan, penelitian, dan pengabdian kepada masyarakat. Dosen merupakan salah satu komponen esensial 
dalam suatu pendidikan di Perguruan Tinggi. Kinerja dosen yang berkualitas sangat dibutuhkan oleh lembaga perguruan tinggi dalam rangka meningkatkan kualitas perguruan tinggi. Kinerja dosen diukur berdasarkan beban kerja dosen mencakup kegiatan pokok yaitu merencanakan pembelajaran, melaksanakan proses bembelajaran, melakukan evaluasi pembelajaran, membimbing dan melatih, melakukan penelitian, melakukan pengabdian pada masyarakat dan melakukan tugas tambahan. Beban kerja dosen sepadan dengan 12 satuan kredit semester (SKS) dan sebanyak banyaknya 16 satuan kredit semester (SKS) (Arwildayanto, 2012: 13). Penilaian kinerja sangat berguna untuk menentukan kebutuhan pelatihan kerja secara tepat, memberikan tanggungjawab yang sesuai kepada karyawan sehingga dapat melaksanakan pekerjaan yang lebih baik di masa mendatang dan sebagai dasar untuk menentukan kebijakan dalam promosi jabatan atau penentuan imbalan. Penilaian kinerja memacu pada suatu sistem formal dan terstruktur yang digunakan untuk mengukur, menilai dan mempengaruhi sifat-sifat yang berkaitan dengan pekerjaan. Menurut Mangkunegara (2017, hal. 10), evaluasi kinerja harus melalui penilaian yang dilakukan secara sistematis untuk mengetahui hasil pekerjaan karyawan dan kinerja organisasi.

\section{METODE PENELITIAN}

Pendekatan dalam penelitian ini adalah dengan menggunakan pendekatan asosiatif, pendekatan asosiatif adalah pendekatan dimana untuk mengetahui bahwa adanya hubungan atau pengaruh diantara kedua variabel (variabel bebas dan variabel terikat). Dalam penelitian ini variabel bebas $X_{1}$ yaitu Kompetensi, $X_{2}$ yaitu Pelatihan, $X_{3}$ yaitu Motivasi dan variabel terikat $Y$ yaitu Kinerja.

\section{a. Operasional Variabel}

Operasional variabel sebagai petunjuk untuk mengukur dan mengetahui baik buruknya pengukuran dalam suatu penelitian pada tabel 1.

\begin{tabular}{|c|c|}
\hline Variabel & Indikator \\
\hline Kinerja $(\mathrm{Y})$ & $\begin{array}{l}\text { 1. Melaksanakan Pendidikan dan } \\
\text { Pengajaran } \\
\text { 2. Melaksanakan Penelitian } \\
\text { 3. Melaksanakan Pengabdian } \\
\text { kepada Masyarakat }\end{array}$ \\
\hline Kompetensi $\left(\mathrm{X}_{1}\right)$ & $\begin{array}{ll}\text { 1. } & \text { Kompetensi Pedagogik } \\
\text { 2. } & \text { Kompetensi Profesional } \\
\text { 3. } & \text { Kompetensi Kepribadian } \\
\text { 4. } & \text { Kompetensi Sosial }\end{array}$ \\
\hline Pelatihan $\left(\mathrm{X}_{2}\right)$ & $\begin{array}{ll}\text { 1. } & \text { Partisipasi } \\
\text { 2. } & \text { Materi Pelatihan } \\
\text { 3. } & \text { Tingkat Kesulitan Kerja } \\
\text { 4. } & \text { Transfer Pengalihan }\end{array}$ \\
\hline Motivasi $\left(\mathrm{X}_{3}\right)$ & $\begin{array}{ll}\text { 1. } & \text { Daya Pendorong } \\
\text { 2. } & \text { Kemauan } \\
\text { 3. } & \text { Kerelaan } \\
\text { 4. } & \text { Keterampilan } \\
\text { 5. } & \text { Kewajiban } \\
\text { 6. } & \text { Tujuan }\end{array}$ \\
\hline
\end{tabular}

B. Teknik Pengumpulan Data

Teknik pengumpulan data penelitian setelah data kuesioner dibagikan kepada responden, selanjutnya angket (kuesioner) penelitian diuji kelayakannya dengan uji validitas dan uji reliabilitas terlebih dahulu. 
Agriprimatech

Vol. 4 No. 1, Oktober 2020

Tabel 2. Teknik Pengumpulan Data

\begin{tabular}{lcc}
\hline & Pertanyaan & Bobot \\
\hline Sangat Setuju & 5 \\
Setuju & 4 \\
Kurang Setuju & 3 \\
Tidak Setuju & 2 \\
Sangat Tidak Setuju & 1 \\
\hline
\end{tabular}

c. Uji Validitas

Menurut Sugiyono (2012, hal. 182) untuk mengukur validitas setiap butir pertanyaan, maka akan menggunakan

teknik korelasi product moment.

$$
t=\frac{r \sqrt{n-2}}{\sqrt{1-r^{2}}}
$$

Dimana :

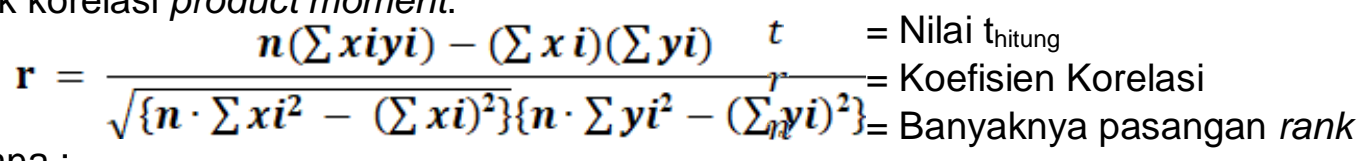
$\mathrm{n}=$ Banyaknya pasangan pengamat\$\$ riteria Pengambilan Keputusan
$\left(\sum x i\right)=$ Jumlah pengamatan variabel $\mathrm{X}_{\mathrm{Bila}} \mathrm{t}_{\text {hitung }}$ lebih kecil dari $\mathrm{t}_{\text {tabel }}$ ( thitung $_{\mathrm{L}}<$
$\left(\sum y i\right)=$ Jumlah pengamatan variaglagel) $Y_{\text {maka }} \mathrm{H}_{0}$ diterima, dan $\mathrm{Ha}$ ditolak.

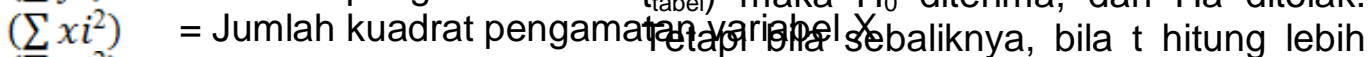

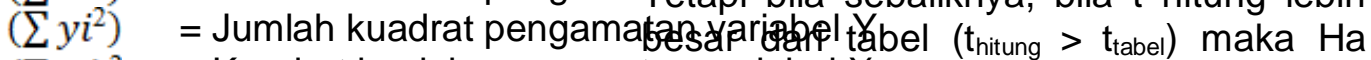
$\left(\sum x i\right)^{2}=$ Kuadrat jumlah pengamatefteriariabel $X$
$\left(\sum y i\right)^{2}=$ Kuadrat jumlah pengamatan variabel $Y$
Exiyi = Jumlah hasil kali variabel $b$ dan Ułi F (Uji Simultan)

\section{d. Uji Reliabilitas}

Pengujian reliabilitas dilakukan dengan menggunakan Cronbach Alpha. Menurut Imam Ghozali (2005, hal. 47) dikatakan reliable bila hasil Alpha $>0.6$, dengan rumus Aplha sebagai berikut :

$$
r=\left[\frac{k}{(k-1)}\right]\left[1-\frac{\sum \sigma b^{2}}{\sigma_{1}^{2}}\right]
$$

Dimana :

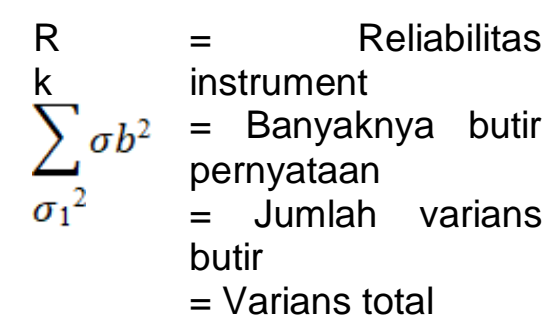

\section{Pengujian Hipotesis}

\section{a. Uji t (Uji Parsial)}

Uji statistik t dilakukan untuk menguji apakah variabel bebas $(X)$ mempunyai hubungan yang signifikan atau tidak terhadap variabel terikat $(\mathrm{Y})$ untuk menguji signifikansi hubungan, digunakan rumus uji statistik t (Sugiyono, 2012, hal. 251) Untuk menguji signifikansi koefisien korelasi berganda maka dihitung dengan menggunakan rumus uji $\mathrm{F}$ sebagai berikut sebagai berikut :

$$
F h=\frac{\frac{R^{2}}{K}}{\frac{\left(1-R^{2}\right)}{(n-k-1)}}
$$

Dimana :

$$
\begin{aligned}
& \mathrm{R} \text { = Koefisien korelasi berganda } \\
& \mathrm{K} \text { = Jumlah variabel independen } \\
& \mathrm{n} \text { = Jumlah sampel } \\
& \mathrm{R}^{2} \text { = Koefisien korelasi berganda yang } \\
& \mathrm{F} \quad \text { telah ditentukan } \\
& \quad=\quad F_{\text {hitung yang selanjutnya }} \\
& \text { dibandingkan dengan } \mathrm{F}_{\text {tabel }} \\
& \text { Kriteria pengujian: }
\end{aligned}
$$

a) Tidak signifikan jika $\mathrm{H}_{0}$ diterima dan Ha ditolak bila $F_{\text {hitung }}<F_{\text {tabel }}$ dan $-F_{\text {hitung }}>-F_{\text {tabel }}$

b) Signifikan jika $\mathrm{H}_{0}$ ditolak dan $\mathrm{Ha}$ diterima bila $F_{\text {hitung }}>F_{\text {tabel }}$ dan $-F_{\text {hitung }}<-F_{\text {tabel }}$ 
Agriprimatech

Vol. 4 No. 1, Oktober 2020

\section{Analisis Koefisien Determinasi}

$\left(R^{2}\right)$

Analisis koefisien determinasi yaitu untuk mengetahui seberapa besar presentase yang dapat dijelaskan variabel kompetensi, pelatihan dan motivasi terhadap kinerja. Adapun rumus perhitungan koefisien determinasi yaitu :

Keterangan :

$$
d=r^{2} \times 100 \%
$$

$$
\begin{array}{ll}
d & =\text { Koefisien determinasi } \\
r & =\text { Nilai korelasi berganda } \\
100 \% & =\text { Persentase kontribusi. }
\end{array}
$$

\section{HASIL DAN PEMBAHASAN}

\section{Uji Validitas dan Reliabilitas}

a. Uji Validitas

Nilai $r$ tabel untuk sampel sebanyak 221 dengan tingkat signifikansi 5\% menunjukkan $r$ tabel sebesar 0.132 . Nilai $r$ tabel $=0.132=(\mathrm{df}=\mathrm{n}-2=221-2=219, \alpha$ $=5 \%$ ). Jika $r$ hitung lebih besar dari $r$ tabel dan nilai $r$ positif maka pernyataan

\begin{tabular}{|c|c|c|c|c|}
\hline Variabel & Item & $\begin{array}{l}\text { Corrected Item-Total } \\
\text { Correlation (r-hitung) }\end{array}$ & $r$ tabel & Keterangan \\
\hline \multirow{10}{*}{ Kompetensi } & $\mathrm{P} 1$ & 0,588 & 0,300 & Valid \\
\hline & $\mathrm{P} 2$ & 0,592 & 0,300 & Valid \\
\hline & P3 & 0,638 & 0,300 & Valid \\
\hline & $\mathrm{P} 4$ & 0,641 & 0,300 & Valid \\
\hline & P5 & 0,514 & 0,300 & Valid \\
\hline & P6 & 0,596 & 0,300 & Valid \\
\hline & $\mathrm{P} 7$ & 0,612 & 0,300 & Valid \\
\hline & $\mathrm{P} 8$ & 0,669 & 0,300 & Valid \\
\hline & $\mathrm{P9}$ & 0,663 & 0,300 & Valid \\
\hline & P10 & 0,574 & 0,300 & Valid \\
\hline \multirow{10}{*}{ Pelatihan } & $\mathrm{P} 1$ & 0,638 & 0,300 & Valid \\
\hline & $\mathrm{P} 2$ & 0,634 & 0,300 & Valid \\
\hline & P3 & 0,678 & 0,300 & Valid \\
\hline & $\mathrm{P} 4$ & 0,737 & 0,300 & Valid \\
\hline & P5 & 0,768 & 0,300 & Valid \\
\hline & P6 & 0,706 & 0,300 & Valid \\
\hline & $\mathrm{P} 7$ & 0,670 & 0,300 & Valid \\
\hline & $\mathrm{P} 8$ & 0,718 & 0,300 & Valid \\
\hline & P9 & 0,743 & 0,300 & Valid \\
\hline & P10 & 0,763 & 0,300 & Valid \\
\hline \multirow{10}{*}{ Motivasi } & $\mathrm{P} 1$ & 0,635 & 0,300 & Valid \\
\hline & $\mathrm{P} 2$ & 0,614 & 0,300 & Valid \\
\hline & P3 & 0,601 & 0,300 & Valid \\
\hline & $\mathrm{P} 4$ & 0,623 & 0,300 & Valid \\
\hline & P5 & 0,636 & 0,300 & Valid \\
\hline & P6 & 0,605 & 0,300 & Valid \\
\hline & $\mathrm{P} 7$ & 0,603 & 0,300 & Valid \\
\hline & $\mathrm{P} 8$ & 0,601 & 0,300 & Valid \\
\hline & P9 & 0,502 & 0,300 & Valid \\
\hline & P10 & 0,664 & 0,300 & Valid \\
\hline
\end{tabular}
tersebut dikatakan valid. Berikut ini adalah hasil uji validitas.

Tabel 3. Hasil Uji Validitas 


\begin{tabular}{lllll}
\hline \multirow{5}{*}{ Kinerja } & P1 & 0,545 & 0,300 & Valid \\
\cline { 2 - 5 } & P2 & 0,635 & 0,300 & Valid \\
\cline { 2 - 5 } & P3 & 0,668 & 0,300 & Valid \\
\cline { 2 - 5 } & P4 & 0,530 & 0,300 & Valid \\
\cline { 2 - 5 } & P5 & 0,636 & 0,300 & Valid \\
\cline { 2 - 5 } & P6 & 0,650 & 0,300 & Valid \\
\cline { 2 - 5 } & P7 & 0,695 & 0,300 & Valid \\
\cline { 2 - 5 } & P8 & 0,726 & 0,300 & Valid \\
\cline { 2 - 5 } & P9 & 0,696 & 0,300 & Valid \\
\cline { 2 - 4 } & P10 & 0,684 & 0,300 & Valid \\
\hline
\end{tabular}

\section{b. Uji Reliabilitas}

Suatu konstruk atau variabel dikatakan reliabel jika memberikan nilai Cronbach Alpha $>0,60$. Hasil uji reliabilitas dapat dilihat pada tabel 4 .

Tabel 4. Hasil Uji Reliabilitas

Variabel

Cronbach's Alpha

\section{Keterangan}

\begin{tabular}{lcc}
\hline Kompetensi & 0,806 & Reliabel \\
\hline Pelatihan & 0,887 & Reliabel \\
\hline Motivasi & 0,802 & Reliabel \\
\hline Kinerja & 0,850 & Reliabel \\
\hline
\end{tabular}

\section{Regresi Linier Berganda}

Berdasarkan hasil pengolahan data yang telah dilakukan, maka dapat diketahui bahwa model hubungan dari analisis regresi linier berganda dapat dilihat pada tabel 5 .

Tabel 5. Hasil Analisis Regresi Linier Berganda

Coefficients $^{\mathrm{a}}$

\begin{tabular}{|c|c|c|c|c|c|c|c|c|}
\hline \multirow[t]{2}{*}{ Model } & \multicolumn{2}{|c|}{$\begin{array}{l}\text { Unstandardized } \\
\text { Coefficients }\end{array}$} & \multirow{2}{*}{$\begin{array}{c}\begin{array}{c}\text { Standardize } \\
d \\
\text { Coefficients }\end{array} \\
\text { Beta }\end{array}$} & \multirow[t]{2}{*}{$\mathrm{t}$} & \multirow[t]{2}{*}{ Sig. } & \multicolumn{3}{|c|}{ Correlations } \\
\hline & B & Std. Error & & & & Zero-order & Partial & Part \\
\hline (Constant) & 9.583 & 2.987 & & 3.208 & .002 & & & \\
\hline $\begin{array}{l}\text { Kompeten } \\
\text { si }\end{array}$ & 279 & .083 & .254 & 3.369 & .001 & .553. & .223 & .178 \\
\hline Pelatihan & .180 & .073 & .181 & 2.452 & .015 & .520 & .164 & .130 \\
\hline Motivasi & .314 & .086 & .279 & 3.645 & .000 & .563 & .240 & .193 \\
\hline
\end{tabular}

a. Dependen Variable: Kinerja 
Berdasarkan tabel 5, maka dapat disusun model penelitian dengan persamaan regresi sebagai berikut :

$Y=9,583+0,279 X_{1}+0,180 X_{2}+0,314 X_{3}$

Model persamaan regresi berganda tersebut bermakna :

a. Nilai Konstanta sebesar 9,583 yang berarti bahwa jika variabel independen yaitu Kompetensi $\left(\mathrm{X}_{1}\right)$, Pelatihan $\left(X_{2}\right)$ dan Motivasi $\left(X_{3}\right)$ sama dengan nol, maka kinerja $(Y)$ adalah sebesar 9,583.

b. Nilai koefisien regresi $X_{1}=0,279$ menunjukkan apabila kompetensi mengalami kenaikan sebesar $100 \%$, maka akan meningkatkan kinerja dosen tetap UNPRI sebesar 27,9\%. Besarnya pengaruh kompetensi terhadap kinerja dosen tetap UNPRI sebesar $14,1 \%$ (hasil perkalian nilai Beta dan Zero-order), yang berarti bahwa kontribusi kompetensi terhadap kinerja dosen tetap UNPRI sebesar $14,1 \%$ sebagai akibat indikatorindikator variabel kompetensi $\left(X_{1}\right)$ dan di luar itu kemungkinan dipengaruhi oleh variabel-variabel yang tidak termasuk dalam penelitian ini. Hal ini dapat dilihat dari nilai standartdied coefficients pada tabel 4.10.

c. Nilai koefisien regresi $X_{2}=0,180$ menunjukkan apabila motivasi mengalami kenaikan sebesar $100 \%$, maka akan meningkatkan kinerja dosen tetap UNPRI sebesar 18,0\%. Besarnya pengaruh pelatihan terhadap kinerja dosen tetap UNPRI sebesar $9,4 \%$ (hasil perkalian nilai Beta dan Zero-order), yang berarti bahwa kontribusi pelatihan terhadap kinerja dosen tetap UNPRI sebesar $9,4 \%$ sebagai akibat indikatorindikator variabel pelatihan $\left(\mathrm{X}_{2}\right)$ dan di luar itu kemungkinan dipengaruhi oleh variabel-variabel yang tidak termasuk dalam penelitian ini. Hal ini dapat dilihat dari nilai standartdied coefficients pada tabel 4.10.

d. Nilai koefisien regresi $X_{3}=0,314$ menunjukkan apabila motivasi mengalami kenaikan sebesar $100 \%$, maka akan meningkatkan kinerja dosen tetap UNPRI sebesar $31,4 \%$. Besarnya pengaruh motivasi terhadap kinerja dosen tetap UNPRI sebesar $15,7 \%$ (hasil perkalian nilai Beta dan Zero-order), yang berarti bahwa kontribusi motivasi terhadap kinerja dosen tetap UNPRI sebesar 15,7\% sebagai akibat indikator-indikator variabel motivasi $\left(X_{3}\right)$ dan di luar itu kemungkinan dipengaruhi oleh variabel-variabel yang tidak termasuk dalam penelitian ini.

Uji Hipotesis

\section{a. Uji Parsial (Uji t)}

Uji statistik t dilakukan untuk menguji apakah variabel bebas $(X)$ secara individual mempunyai pengaruh yang signifikan atau tidak terhadap variabel terikat $(\mathrm{Y})$.

Tabel 6. Hasil Uji Parsial (Uji t)

Coefficients $^{\mathrm{a}}$

\begin{tabular}{|c|c|c|c|c|c|}
\hline \multirow[t]{2}{*}{ Model } & \multicolumn{2}{|c|}{$\begin{array}{c}\text { Unstandardized } \\
\text { Coefficients }\end{array}$} & \multirow[t]{2}{*}{ Standardized Coefficients } & \multirow[t]{2}{*}{$\mathrm{t}$} & \multirow[t]{2}{*}{ Sig. } \\
\hline & $B$ & Std. Error & & & \\
\hline (Constant) & 9.583 & 2.987 & & 3.208 & .002 \\
\hline Kompetensi & .279 & .083 & .254 & 3.369 & .001 \\
\hline Pelatihan & .180 & .073 & .181 & 2.452 & .015 \\
\hline Motivasi & .314 & .086 & .279 & 3.645 & .000 \\
\hline
\end{tabular}

a. Dependen Variable: Kinerja 
1) Pengaruh Kompetensi Terhadap Kinerja

Berdasarkan tabel 6, dapat diketahui bahwa variabel kompetensi $\left(X_{1}\right)$ memiliki nilai signifikansi sebesar 0,001 lebih kecil dari 0,05 , artinya bahwa kompetensi berpengaruh signifikan terhadap kinerja dosen tetap UNPRI.

Dari tabel 6, tentang pengaruh kompetensi $\left(\mathrm{X}_{1}\right)$ terhadap kinerja $(\mathrm{Y})$ diperoleh nilai thitung $3,369>t_{\text {tabel }} 1,971$ dengan probabilitas Sig 0,001 lebih kecil dari $\alpha=0,05$. Dapat disimpulkan bahwa kompetensi secara parsial mempunyai pengaruh signifikan terhadap kinerja dosen tetap UNPRI.

\section{2) Pengaruh Pelatihan Terhadap Kinerja}

Berdasrkan tabel 6, dapat diketahui bahwa variabel pelatihan $\left(\mathrm{X}_{2}\right)$ memiliki nilai signifikansi sebesar 0,015 lebih kecil dari 0,05, artinya bahwa kompetensi berpengaruh signifikan terhadap kinerja dosen tetap UNPRI.

Dari tabel 6, tentang pengaruh pelatihan $\left(\mathrm{X}_{2}\right)$ terhadap kinerja $(\mathrm{Y})$ diperoleh nilai thitung $2,452>t_{\text {tabel }} 1,971$ dengan probabilitas Sig 0,015 lebih kecil dari $\alpha=0,05$.

\section{3) Pengaruh Motivasi Terhadap Kinerja}

Berdasarkan tabel 6, dapat diketahui bahwa variabel motivasi $\left(X_{3}\right)$ memiliki nilai signifikansi sebesar 0,000 lebih kecil dari 0,05 , artinya bahwa motivasi berpengaruh signifikan terhadap kinerja dosen tetap UNPRI.

Dari tabel 6, tentang pengaruh motivasi $\left(\mathrm{X}_{3}\right)$ terhadap kinerja $(\mathrm{Y})$ diperoleh nilai thitung $3,645>t_{\text {tabel }} 1,971$ dengan probabilitas Sig 0,000 lebih kecil dari $\alpha=0,05$. Dapat disimpulkan bahwa motivasi secara parsial mempunyai pengaruh signifikan terhadap kinerja dosen tetap UNPRI.

\section{b. Uji Simultan (Uji F)}

Uji statistik $F$ (simultan) dilakukan untuk mengetahui apakah variabel bebas (independen) secara bersama-sama berpengaruh secara signifikan atau tidak terhadap variabel terikat (dependen). Hasil uji secara simultan dapat dilihat pada tabel 4.16.

Tabel 7 Hasil Uji Simultan (Uji F)

\begin{tabular}{|rl|r|r|r|r|r|}
\hline Model & & Sum of & \multicolumn{1}{|c|}{ df } & Mean Square & $\mathrm{F}$ & Sig. \\
& & Squares & & & & \\
\hline \multirow{3}{*}{1} & Regression & 1231.117 & 3 & 410.372 & 46.640 & $.000^{\mathrm{b}}$ \\
& Residual & 1909.309 & 217 & 8.799 & & \\
& Total & 3140.425 & 220 & & & \\
\hline
\end{tabular}

a. Dependen Variable: Kinerja

b. Predictors: (Constant), Motivasi, Pelatihan, Kompetensi

Berdasarkan tabel 7, dapat dilihat bahwa terdapat nilai signifikansi sebesar 0,000 lebih kecil dari $\alpha=0,05$. Hal ini menunjukkan bahwa kompetensi, pelatihan dan motivasi secara bersamasama berpengaruh signifikan terhadap kinerja dosen tetap UNPRI.

Jika dibandingkan nilai $\mathrm{F}_{\text {hitung }}$ dengan $F_{\text {tabel }}$ yakni $46,640>2,65$, maka dapat disimpulkan bahwa kompetensi, pelatihan dan motivasi secara bersama-sama berpengaruh signifikan terhadap kinerja dosen tetap UNPRI.

\section{c. Analisis Koefisien Determinasi $\left(R^{2}\right)$ \\ Uji koefisien determinasi dilakukan} untuk melihat seberapa besar variabel kompetensi, pelatihan dan motivasi dalam menjelaskan variasi variabel dependen yaitu kinerja. Hasil uji koefisien determinasi dapat dilihat pada tabel 8 . 
Tabel 8. Hasil Uji Koefisien Determinasi

Model Summary ${ }^{b}$

\begin{tabular}{|l|r|r|r|r|}
\hline Model & \multicolumn{1}{|c|}{$\mathrm{R}$} & R Square & Adjusted R Square & Std. Error of the Estimate \\
\hline 1 & $.626^{\mathrm{a}}$ & .392 & .384 & 2.96625 \\
\hline
\end{tabular}

a. Predictors: (Constant), Motivasi, Pelatihan, Kompetensi

b. Dependen Variable: Kinerja

Berdasarkan tabel 8, diketahui bahwa nilai $R_{\text {square }}$ adalah sebesar 0,392 atau sama dengan $39,20 \%$. Artinya bahwa kompetensi, pelatihan dan motivasi mampu untuk menjelaskan kinerja dosen tetap UNPRI sebesar 39,20\% dan sisanya $60,80 \%$ dijelaskan oleh variabel bebas yang lainnya yang tidak diikutsertakan ke dalam model penelitian ini.

\section{Pembahasan}

Hasil pengujian, terlihat bahwa semua variabel bebas kompetensi $\left(X_{1}\right)$, pelatihan $\left(X_{2}\right)$ dan motivasi $\left(X_{3}\right)$ mempunyai pengaruh signifikan terhadap variabel kinerja (Y). Untuk lebih jelasnya, rincian hasil analisis dan pengujian tersebut dapat dijelaskan sebagai berikut:

1. Pengaruh Kompetensi Terhadap Kinerja. Berdasarkan hasil penelitian mengenai pengaruh antara kompetensi terhadap kinerja pada dosen tetap UNPRI yang menyatakan $t_{\text {hitung }}>t_{\text {tabel }}$ yaitu $3,369>1,971$ berada di daerah penolakan $\mathrm{H}_{0}$ sehingga $\mathrm{Ha}$ diterima, hal ini dinyatakan bahwa kompetensi berpengaruh signifikan secara parsial terhadap kinerja dosen tetap UNPRI.

2. Pengaruh Pelatihan terhadap Kinerja . Berdasarkan hasil penelitian mengenai pengaruh antara pelatihan terhadap kinerja pada dosen tetap UNPRI yang menyatakan thitung $>$ ttabel yaitu 2,452 > 1,971 berada di daerah penolakan $\mathrm{HO}$ ᄀ sehingga $\mathrm{Ha}$ diterima, hal ini dinyatakan bahwa pelatihan berpengaruh signifikan secara parsial terhadap kinerja dosen tetap UNPRI.

3. Pengaruh Motivasi terhadap Kinerja. Berdasarkan hasil penelitian mengenai pengaruh antara motivasi terhadap kinerja pada Dosen Tetap UNPRI yang menyatakan thitung $>$ ttabel yaitu $3,645>1,971$ berada di daerah penolakan $\mathrm{HO}$ sehingga $\mathrm{Ha}$ diterima, hal ini dinyatakan bahwa motivasi berpengaruh signifikan secara parsial terhadap kinerja dosen tetap UNPRI.

4. Pengaruh Kompetensi, Pelatihan dan Motivasi terhadap Kinerja. Pengaruh antara kompetensi, pelatihan dan motivasi terhadap kinerja dosen tetap UNPRI, pada penelitian ini sudah jelas terbukti ada pengaruh secara simultan, berdasarkan hasil uji $F$ diperoleh nilai Fhitung > Ftabel yaitu 46,640 > 2,65 dengan signifikansi sebesar $0,000<$ 0,05. Karena Fhitung > Ftabel maka $\mathrm{HO}$ ditolak dan $\mathrm{Ha}$ diterima, artinya ada pengaruh antara kompetensi, pelatihan dan motivasi terhadap kinerja dosen tetap UNPRI.

\section{KESIMPULAN}

Berdasarkan hasil penelitian dan pembahasan yang dilakukan oleh peneliti mengenai pengaruh kompetensi, pelatihan dan motivasi terhadap kinerja dosen tetap UNPRI, maka dapat ditarik kesimpulan yaitu kompetensi, pelatihan dan motivasi secara simultan berpengaruh signifikan terhadap kinerja. Besarnya pengaruh kompetensi, pelatihan dan motivasi mampu untuk menjelaskan kinerja dosen tetap UNPRI sebesar $39,20 \%$ dan sisanya $60,80 \%$ dijelaskan oleh variabel bebas yang lainnya yang tidak diikutsertakan ke dalam model penelitian ini.

\section{DAFTAR PUSTAKA}

Adriyanto, H dan Surbakti AG. 2018. Pengaruh Pelatihan, Motivasi dan Kompetensi Terhadap Kinerja Karyawan (Studi Kasus Hotel 
Sahid Jaya Lippo Cikarang). Journal of Indonesian Tourism, Hospitality and Recreation, Vol. 1, No. 2.

Agustini, Fauzia (2011). Manajemen Sumber Daya Manusia Lanjutan, Edisi Pertama. Medan: Penerbit Madenatera.

Arwildiyanto. (2012). Manajemen Sumber Daya Manusia Perguruan Tinggi; Pendekatan Budaya Kerja Profesional. Goronalo: Ideas Fublishing.

Bangun, SD. 2017. Analisis Pengaruh Dana Sertifikasi Dosen Serta Pendidikan dan Pelatihan Terhadap Kinerja Dosen Fakultas MIPA Universitas Sumatera Utara. Skripsi. Medan : Penelitian Universitas Sumatera Utara.

Elizar dan Hasrudy Tanjung (2018). Pengaruh Pelatihan, Kompetensi, Lingkungan Kerja terhadap Kinerja Pegawai. Jurnal IImiah Magister Manajemen, Vol 1, No. 1.

Hasibuan, S.P Malayu (2010). Organisasi dan Motivasi Dasar Peningkatan Produktivitas. Cetakan Ke-7. Jakarta: PT Bumi Aksara.

Hutapea, Parulian dan Nuriana Thoha (2008). Kompetensi Komunikasi Plus: Teori, Desain, Kasus dan Penerapan Untuk HR dan Organisasi yang Dinamis. Jakarta: Gramedia Pustaka Utama.

Indrarini. 2009. Pengaruh Motivasi dan Kepuasan Kerja Terhadap Kinerja Dosen Akademi Swasta Di Kota Semarang. Tesis. Semarang: Penelitian Universitas Negeri Semarang.
Kasmir (2016). Manajemen Sumber Daya Manusia. Cetakan ke-1. Jakarta: PT. Raja Grafindo Persada.

Kholik, A. 2016. Pengaruh Kompetensi Dosen dan Kepuasan Kerja Dosen Terhadap Kinerja Dosen Di Universitas Djuanda Bogor. Tesis. Bogor: Penelitian Intitut Agama Islam Negeri Surakarta.

Mangkuprawira. 2007. Manajemen Sumber Daya Manusia Strategik. Jakarta: Ghalia Indonesia.

Nitisemito, AS. 2007. Manajemen Sumber Daya Manusia. Edisi Ketiga. Cetakan Kesembilan. Yogyakarta: Ghalia Indonesia.

Palan, R. (2007). Competency Management : Teknis Mengimplementasikan

Manajemen SDM Berbasis Kompetensi Untuk Meningkatkan Daya Saing Organisasi. Jakarta: PPM.

Rivai, Veithzal (2014). Manajemen Sumber Daya Manusia untuk Perusahaan. Edisi Ke-6, Depok: PT. Raja Grafindo Persada.

Rohimah, S. 2013. Pengaruh Kompetensi, Kompensasi, Disiplin Kerja Terhadap Kinerja dan Kepuasan Kerja Guru SMA Islamic Village Karawaci Tangerang. Tesis. Jakarta : Penelitian Universitas Esa Unggul.

Sastrohadiwiryo, BS. 2010. Manajemen Tenaga Kerja Indonesia Pendekatan Administrative dan Operasional. Jakarta: Bumi Aksara. 